\title{
sciendo
}

EUROPEAN SPATIAL RESEARCH AND POLICY

Volume 25

Number 2

http://dx.doi.org/10.18778/1231-1952.25.2.04

\author{
Dagmara KOCIUBA*, Edyta SZAFRANEK**
}

\section{NEW TOOL FOR MEASURING SUSTAINABLE DEVELOPMENT IN FUNCTIONAL URBAN AREAS}

\begin{abstract}
The article discusses the practical aspect of implementation of the idea of sustainable development in the EU Cohesion Policy in the 2014-2020 programming period in Poland. The objective of the study is to determine the relations between the idea of sustainable development and instruments of its implementation, and the identification of the scope of influence of Cohesion Policy tools on sustainable development of functional urban areas (FUA). The paper presents the author's set of sustainable development indicators (SDI) and relevant analyses of their implementation in the financial and spatial aspect in 26 FUAs. Detailed analyses covered one of the new instruments of territorial development, namely Integrated Territorial Investments (ITI). The paper provides evidence which proves that the dominant sphere in the financial and spatial support is the modernisation of transport and energy engineering infrastructure, with potentially multiple effects, as well as the development of a structurally diverse labour market. The least support is provided to the strengthening of integrated management. The tested approach is applicable in reference to other functional areas in the EU. It can contribute to the determination of the extent to which the implementation of the Cohesion Policy supports sustainable development of cities and their functional areas. The application of SDI contributed to the understanding of the process in reality.
\end{abstract}

Keywords: sustainable development indicators (SDI), sustainable development, Functional Urban Area (FUA), Integrated Territorial Investments (ITI), Cohesion Policy 2014-2020, Poland.

\section{INTRODUCTION}

Sustainable development is continuing challenge of the EU development policy, transferred as a strategic objective to the Europe 2020 Strategy (2010). The implementation of the concept assuming conducting economic activity and an

\footnotetext{
* Dagmara KOCIUBA, Maria Curie-Sklodowska University, Faculty of Earth Sciences and Spatial Management, Department of Spatial Policy and Planning, 20-718 Lublin, Kraśnicka 2d, Poland; e-mail: dagmara.kociuba@poczta.umsc.lublin.pl

** Edyta SZAFRANEK, University of Opole, Faculty of Economics, Department of Economic Geography and Spatial Economy, 45-058 Opole, Ozimska 46a, Poland; e-mail: eszafranek@uni.opole.pl
} 
organisation of social life in a way that ensures sustainability and the dynamics of development processes and stability of the use of environmental resources in the present programming period requires the integration of activities in several dimensions: economic, social, environmental, and spatial. Moreover, it is emphasised that detailed objectives of sustainable development should depend on local conditions and the needs of local communities (Borys, 2005; Galaz, 2014; Mierzejewska, 2015, 2017; Dembicka-Niemiec, 2017). Therefore, in the present programming period, the implementation of the rules of sustainable development, particularly in urban areas the role of which is increasingly emphasised in the EU policy (Bartniczak, 2016; Danielewicz, 2017; Farole et al., 2011; Hens, 2010; McCann and Ortega-Argilés, 2013), requires a harmonisation of the objectives of social-economic and territorial development, and simultaneously addressing development mechanisms to designated 'places' defined as functional areas covering a compact urban area and the functionally related urban zone. The most important aspects in the financial context include the concentration of intervention enabling the elimination of wastage and dispersal of resources, and an integration of performed measures, also in the programming and governing sphere.

New instruments were introduced for an effective implementation of this concept of development in the programming period 2014-2020. Those are functional urban areas (FUAs) supporting the strengthening of territorialisation and an integration of interventions, and Integrated Territorial Investments (ITIs) permitting the introduction of new rules in the scope of the management of EU funds. They are closely interrelated. The implementation of ITIs aims, on the one hand, at creating rules of territorially integrated management of FUA development (Kaczmarek and Kociuba, 2017), and, on the other, at increasing the effectiveness of Cohesion Policy interventions (Szafranek, 2014; Kociuba, 2017). Those are two areas of key importance for a sustainable development of cities, and their functional areas.

In the presented context, it was assumed that instruments of the 2014-2020 Cohesion Policy should consider the needs of sustainable development and of urban areas, and affect their shaping. In the cognitive sphere, the objective of the study is to determine the relations between the idea and instruments of the implementation of a sustainable development of FUAs. The implementation sphere involves the presentation of a proposal for a new tool for the assessment/evaluation of the scope of the effect of ITIs on the sustainable development of FUAs. The paper employs the author's original group of so called sustainable development indicators (SDIs). They enabled the performance of relevant analyses, in the financial and spatial aspect, concerning the implementation of ITIs in the context of the implementation of SDIs. The research was conducted for 26 functional urban areas which in a broader context can be treated as examples of units designated for the implementation of ITIs in EU Member States. Thus, the implementation of the idea of sustainable development in functional urban areas was presented in the practice of the 2014-2020 EU Cohesion Policy in Poland. 


\section{SUSTAINABLE DEVELOPMENT IN THEORY AND DEVELOPMENT POLICY - OVERVIEW OF THE ISSUE}

Sustainable development is a research concept discussed in the context of various sciences, particularly economic and environmental, and technical sciences. A broad approach, i.e. considering various scientific aspects, is discussed by, e.g.: Adams (1990), Borys (2005), Borys and Czaja (2009), Brown (2001), Dobson (1996), Lafferty (1999), Mierzejewska (2017), Papuziński (2011), Piątek (2007), Stanny and Czarnecki (2011). The subject of this study corresponds to the socio-economic and political context of the research, therefore the concept of sustainable development is examined in the context of economic sciences.

Researchers who discuss the theory of economics have indicated that the theory of sustainable development evolved over many years, and originated from classic economics, represented by, i.a. Ricardo, Mill, and Malthus (Płachciak, 2011). The discussion which began in the 1960s on balancing the development of countries and regions resulted in an increased focus on the depletion of resources and the damage of widely available goods considered as common, as well as on the effects of the processes of the excessive use and devastation of the natural environment. Initially, the antidote to the problems was sought in the necessity to impose rules on local communities to adjust the intensity of the use of environmental resources to their natural capacity for regeneration (renewal) (Hardin, 1968), Moreover, it was stressed that the efficient use of goods and resources entails the necessity to introduce rules of integrated governance, implement alternative strategies of development, and implement new technological solutions (Diwan and Livingston, 1979; Hawken et al., 1999; Brown, 2001).

Attempts at shaping policies of development were undertaken in accordance with the rules of 'zero growth', and when such a policy proved impossible to implement - 'limited growth'. The policies, however, did not bring the expected results. That encouraged countries to reflect on the necessity to implement new solutions in the context of growing restrictions in the use of resources, and a need for increasing diligence in protecting the natural environment. A key role in the processes was played by measures undertaken internationally at the end of the 1980s. The publication of the report entitled "Our Common Future" (Brundtland report) in 1987, and then documents summarising the II UN Conference in 1992, i.e.: "Rio Declaration of Environment and Development" and "Action Programme - Agenda 21", on the one hand, contributed to the development of specific recommendations for shaping the rules of sustainable development (Adams, 1990; Dobson, 1996; Lafferty, 1999; Reid, 1995), and, on the other, became a source of instructions for the preparation of development programmes for all levels of territorial units (from the local to the international level). 
The conditions and needs of the implementation of the rules of sustainable development have changed over the 30 years since the arrangements (Sneddon et al., 2006, p. 263-264). Nonetheless, the core concept remains the same (Byrne and Glower, 2002). Currently, sustainable development constitutes an idea providing the basis for building efficient economic systems, in the sphere of both micro and macroeconomics (Fiedor, 2011; Sadowski, 2006; Żylicz, 2000). It is described as a maximisation of net benefits from economic development, protecting and ensuring the recreation of the usefulness and quality of natural resources in a long-term (Pearce and Turner, 1990). The next important aspect of sustainable development idea is its multidimensionality (Adams, 2006; Borys, 1998, 2005; Dembicka-Niemiec, 2017; Hull, 2011; Kassenberg, 2007; Mierzejewska, 2015, 2017). Sustainable development is usually presented as a harmonisation of dimensions: economic, social, ecological, and spatial. Such an approach of the concept is addressed directly by Leśniak $(2009$, p. 7$)$ who claimed that it is "a socially indicated, economically purposeful, and ecologically desired strategy of economic development". The success of its execution is related to the implementation of a development policy adjusting institutions and activities in the economic and social spheres in accordance with environmental values and conditions (Byrne and Glower, 2002, p. 11). In the strategic-programming sphere, the condition of implementation of the concept of sustainable development is the concurrent implementation of four policies: ecological, economic, social, and spatial, and the system of governance of territorial units.

Such a stance was adopted in the assumptions of strategic development of the EU which were implemented in accordance with the integrated territorial approach. It was established as a result of changes in public policies in the EU, somewhat forced in the programming of development to shift from a sectoral to integrated and territorial approach (Barca et al., 2012). It is characterised by a focus on the use of endogenous potentials of functionally specified territories, an integration of public activities in the spatial dimension, and a well-developed system of multi-level governance. Such activities support obtaining competitive advantages by regions and countries (Barca, 2009). The approach became stronger with the reorientation of the distribution of resources in the first decade of the $21^{\text {st }}$ century (Farole et al., 2011; Szlachta and Zaucha, 2012). The new paradigm of the development of the EU was introduced by the Lisbon Treaty (2007, coming into force in 2009), and established in the "Europe 2020. A strategy for smart, sustainable and inclusive growth" approved in 2010. The document specified three basic pillars of EU development by 2020. One of them is sustainable development, denoting support of the economy efficiently using resources, more environmentally-friendly, and more competitive (Europe, $2020,2010)$. Therefore, sustainable development found complete reflection in the 2014-2020 Cohesion Policy directly implementing the provisions of the Europe 2020 Strategy. 
Territorialisation of measures aimed at the implementation of rules of sustainable development is yet another issue. As emphasised by Dembicka-Niemiec (2017), "the concept of sustainable development currently plays an important role in creating directions of the development of various territorial systems, and increasingly frequently refers to cities". This is particularly related to changes in the perception of the role of cities in the development of EU countries commenced in 2007 by adopting the Leipzig Charter for sustainable development of European cities, where cities and their functional areas were ascribed the key role in the development of regions and building their territorial cohesion. The need for maintaining an urban policy in accordance with the rules of sustainable development was also recognised, and the benefits of such measures were indicated (Marcial et al., 2012).

In referring the presented assumptions of sustainable development to the idea of implementation of the integrated territorial approach through EU policy, the concepts prove to coincide. Territorial development must consider rules of sustainable development, and the implementation of the rules of sustainable development must be of a territorial nature (Szafranek, 2014). Moreover, both concepts directly apply to urban areas.

\section{TOOLS OF TERRITORIAL DEVELOPMENT OF CITIES AND THEIR FUNCTIONAL AREAS IN THE 2014-2020 COHESION POLICY}

Two new tools appeared in the context of the territorialisation of the interventions of the Cohesion Policy supporting efficient development of cities in the 20142020 programming period. In the planning-strategic aspect, those are functional urban areas (FUAs), and in the financial aspect: the Integrated Territorial Investments (ITIs). Both tools are aimed at supporting the sustainable development of cities and their functional areas.

The designation of FUAs resulted from the need of territorial integration. The introduction of functional urban areas in the Polish spatial planning system co-occurred with the adoption of the National Spatial Development Concept 2030 (hereinafter: NSDC, 2030) (2011). According to NSDC 2030, a functional urban area is a spatially continuous settlement system composed of separate administrative units. It covers a compact urban area and the functionally related urbanised zone. In administrative terms, such areas can cover urban, rural, and urban-rural communes (p. 187). NSDC 2030 introduced the typology of FUAs considering cores and external zones. Four basic types of FUAs were identified based on the size of the centre (p. 181). Those are functional urban areas of: 
1. Voivodship centres (FUA VC), including metropolitan (metropolitan areas) - all voivodship capitals;

2. Regional centres (FUA RC) not constituting voivodship capitals but playing a substantial role in the economic, social, and administrative life of the regions and the country, with a population between 100,000 and 300,000;

3. Subregional centres (FUA SC) concentrating economic and social functions with a regional range supplementary towards centres of the higher level, with a population of $50,000-100,000$;

4. Local centres (FUA LC) with development capacities at the supralocal scale, with a population of less than 50,000, including some poviat cities.

Pursuant to the guidelines of the European Parliament, the implementation of ITIs is aimed at the strengthening the urban dimension in the Cohesion Policy, and constitutes a legal response of the European Commission to the necessity of strengthening the integrated approach to programming development combining policies, sectors, and funds, postulated by Member States in recent years. ITI implementation has twofold importance: 1) in the sphere of governance, it supports promoting the partnership model of the cooperation of local government units (LGUs) (Kociuba, 2017; Kaczmarek and Kociuba, 2017), and 2) in the programming sphere, it supports the development of FUAs and strengthens their impact on the surroundings (Szafranek, 2014). The launch of an ITI requires achieving several ex-ante conditions, the most important of which being having an integrated intersectoral territorial strategy - ITI Strategy, and formalised partnerships of an LGU included in a given FUA through the establishment of an ITI Union. Activities stipulated in the strategy are implemented in the form of bundles of projects financed from several priority axes and operational programmes, whereas it is possible to combine the financing of one project from various funds (ERDF, ESF and Cohesion Fund). ITI Unions have the minimum scope of delegating tasks in the scope of managing allocation within operational programmes and they are responsible for the implementation of provisions of ITI Strategies (European Commission, 2014). ITIs are aimed at supporting the sustainable development of cities and their functional areas by strengthening the territorialisation of interventions and the promotion of the cooperation of administrative units included in a given functional area (Principles..., 2013). Therefore, the ITIs should strengthen and facilitate the financial programming, and governing aspect measures related to the implementation of the idea of sustainable development in functional urban areas. In the case of Poland, they are FUAs of voivodship centres obligatorily, and - based on the decision of voivodship authorities - regional and subregional centres. The group of indicators proposed further in the paper can facilitate the assessment of the effect of measures related to the implementation of ITIs in the context of sustainable development of functional areas implementing the instrument. 


\section{SUSTAINABLE DEVELOPMENT OF CITIES AND ITI IMPLEMENTATION}

\subsection{Sustainable Development Indicators (SDIs) - rationale, methodology}

Due to their local and supralocal effect, FUAs correspond to the concept of sustainable development of cities presented by Mierzejewska $(2015,2017)$. According to the cited author (Mierzejewska, 2017, p. 74), two groups of models of sustainable development of cities can be distinguished, namely: 1) approach based on the development of the internal structure of a city (spatial and socio-economic), and 2) approach concerning the ordering relations between a city and its surroundings (supraregional dimension). Both approaches are not divergent, because they reflect the complexity of the problem both in the structural and the territorial dimensions. Each of the concepts should be implemented in an individualised manner, relevant to the conditions and needs for development of urban areas. Nonetheless, the necessity to undertake specified measures facilitating sustainable development of each city is emphasised. According to Mierzejewska (2017, p. 76), such measures include:

- increasing the density of population and buildings,

- revitalising degraded and dysfunctional areas,

- improving the accessibility of high quality public areas,

- increasing the diversity of a city (particularly social, but also in terms of land use and in the environmental sphere),

- mixing different forms of land use,

- developing balanced forms of transport (public, bicycle, pedestrian traffic),

- expanding urban greenery,

- recycling and modern systems of waste collection and utilisation,

- efficient energy management, including the use of renewable energy sources and limiting heat losses (e.g. through the thermal modernisation of buildings, the replacement of window frames),

- moulding the city's spatial order, including its design and architecture.

The aforementioned measures for sustainable development of urban areas can be implemented using different tools. In the current programming period, in the programming-financial-governing aspect, those particularly include ITIs. It should be emphasised that the implementation of the tool itself does not offer the possibility of ex-post evaluation of the effect (or its lack) of planned and implemented investments and measures on the sustainable development of functional urban areas. No tools for this type of evaluation have been developed so far. That is the task of units responsible for the development and implementation of ITI strategies. Their role in the scope is usually limited to designating the indicators of a product and an effect concerning specific measures and projects (bundles of pro- 
jects), and monitoring their implementation. In practice, that has little to do with EU assumptions because sustainable development requires a complex assessment of the effects of an ITI on the development of an FUA. Therefore, this paper proposes a new tool for the evaluation of the effect of the implementation of the tools of the Cohesion Policy on sustainable development of cities and their functional areas, namely Sustainable Development Indicators (SDIs).

Initially, detailed analyses covered categories of sustainable development of cities corresponding to the issues of projects financed through ITIs, as well as categories resulting from guidelines for the implementation of ITIs in Poland (Principles..., 2013; Programming..., 2014). A total of 10 categories of development that can be currently regarded as features of sustainable urban areas were analysed. Thus the so-called Sustainable Development Indicators (SDIs) of functional urban areas were obtained. Those can be amplified through the implementation of ITIs. Those include:

1. Development of modern and innovative economy;

2. Integrated governance;

3. Low emission economy and an increase in the utilisation of renewable energy sources (RES);

4. Development of sustainable transport, and improvement of mobility within the local and regional system;

5. Improvement of the state of the natural environment (protection and development of biodiversity, including green areas and public areas);

6. Rational municipal economy;

7. Development of structurally diverse labour market;

8. Social activeness and integration;

9. Regeneration of degraded and dysfunctional areas;

10. Improvement of the quality and availability of public services.

Subsequently, it was assumed that creating sustainable development of urban areas through the implementation of ITIs occurs through the implementation of measures and projects under selected investment priorities (IPs) specified in ITI strategies. ${ }^{1}$ Therefore, SDIs were associated with IPs included in ITI Strategies implemented in all $17 \mathrm{FUA} \mathrm{VC},{ }^{2}$ and those among regional and subregional cen-

\footnotetext{
${ }^{1}$ IPs are closely related to the thematic objectives (TO) of the EU Cohesion Policy for the years 20142020 specified in Art. 9 of the Regulation (EU) No. 1303/2013 of the European Parliament and of the Council of 17 December 2013. Those include: TO1 - Research and innovation; TO2 - Information and communication technologies; TO3 - SMEs competitiveness; TO4 - Low-carbon economy; TO5 Climate change and risk prevention; TO6 - Environment and resource efficiency; TO7 - Transport and energy networks; TO8 - Employment and labour market; TO9 - Social inclusion; TO10 - Education and training. The list of corresponding investment priorities is included in Tab. 1.

${ }^{2}$ Those include: Białystok FUA, Bydgoszcz-Toruń FUA, Kielce FUA, Cracow FUA, Lublin FUA, Łódź FUA, Opole FUA, Gorzów Wielkopolski FUA, Olsztyn FUA, Poznań FUA, Katowice FUA, Tricity FUA, Zielona Góra FUA, Rzeszów FUA, Szczecin FUA, Warsaw FUA, Wrocław FUA.
} 
tres which obtained financing under the restricted call for proposals under the regional operational programmes (ROPs). ${ }^{3}$ The system of SDI and the corresponding IPs is presented in Fig. 1.

Sustainable Development Indicators (SDI)

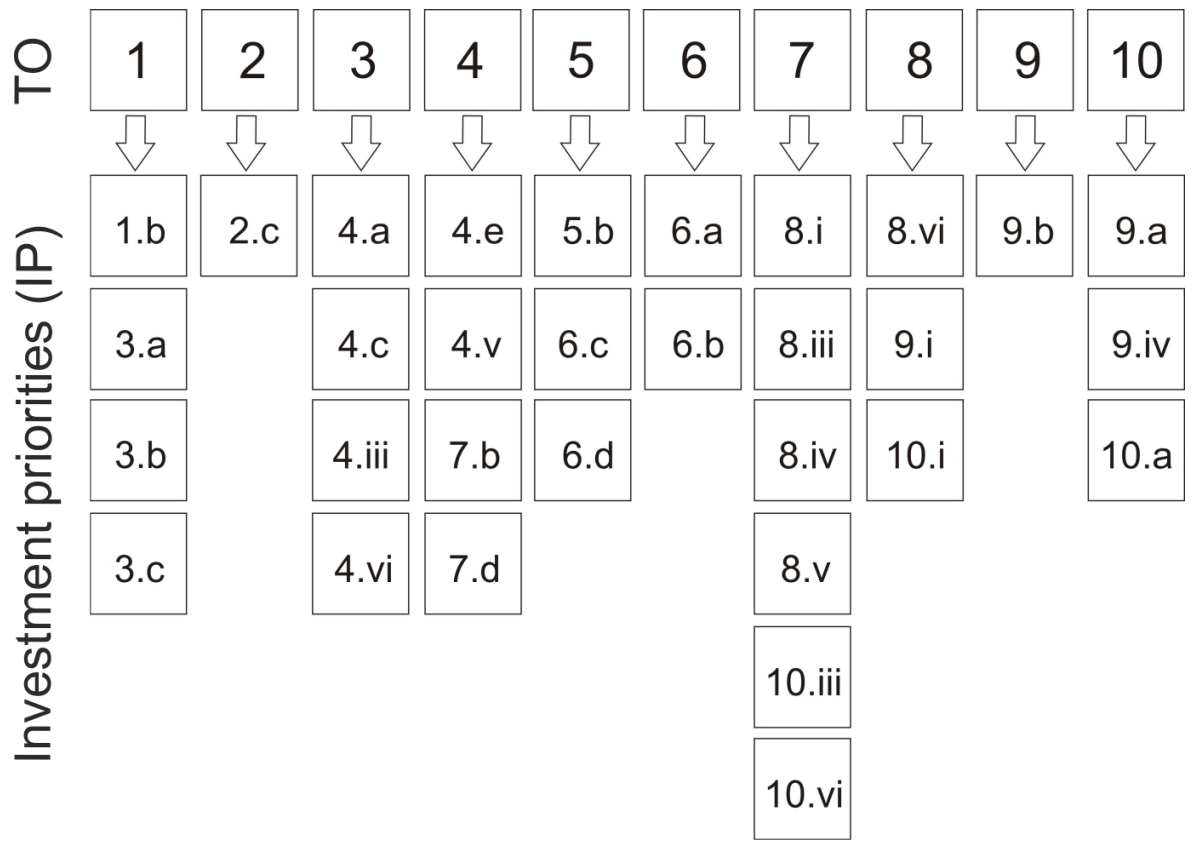

Fig. 1. Sustainable Development Indicators (SDI) with the corresponding Investment priorities (IP) Source: own work.

\subsection{Implementation of ITIs in functional urban areas in the context of sustainable development - practice}

The key aspect of the possibilities of implementing the assumptions of sustainable development of FUAs is the availability of financial resources. In the period 2014-2020, a considerable part of those is distributed to such areas through ITI.

Table 1 presents the scale of financing of tasks implemented under particular investment priorities in the analysed 26 FUAs ascribed to the specified Sustainable Development Indicators (SDIs).

\footnotetext{
${ }^{3}$ Those include: Kalisz-Ostrów FUA, Elbląg FUA, Ełk FUA, Koszalin-Kołobrzeg-Białogard FUA, Bielsko-Biała FUA, Częstochowa FUA, Rybnik FUA, Jelenia Góra FUA, Wałbrzych FUA.
} 
Table 1. Financial value of tasks implemented through ITI in the scope of creating sustainable development of FUA

\begin{tabular}{|c|c|c|c|}
\hline \multirow{2}{*}{ Indicator } & \multirow{2}{*}{ Investment priority } & \multicolumn{2}{|c|}{ Value in euro } \\
\hline & & Per priority & Total \\
\hline \multirow{4}{*}{1} & $\begin{array}{l}\text { 1.b Promoting investments of enterprises in } \\
\text { D\&I, development of knowledge transfer and } \\
\text { commercialisation }\end{array}$ & $2,823,529$ & \multirow{4}{*}{$353,718,009$} \\
\hline & 3.a Promoting entrepreneurship & $302,260,745$ & \\
\hline & $\begin{array}{l}\text { 3.b Development and implementation of new } \\
\text { business models for small and medium-sized } \\
\text { enterprises }\end{array}$ & $13,993,212$ & \\
\hline & $\begin{array}{l}\text { 3.c Creating and expanding advanced skills in } \\
\text { development of products and services }\end{array}$ & $34,640,523$ & \\
\hline 2 & $\begin{array}{l}\text { 2.c Strengthening of the application of ICT in } \\
\text { e-administration, e-learning, e-social inclusion, } \\
\text { e-culture, and e-health }\end{array}$ & $48,591,561$ & $48,591,561$ \\
\hline \multirow{4}{*}{3} & $\begin{array}{l}\text { 4.a Support of the production and distribution of } \\
\text { energy derived from renewable sources }\end{array}$ & $133,113,725$ & \multirow{4}{*}{$858,782,517$} \\
\hline & $\begin{array}{l}\text { 4.c Support of energetic efficiency, smart energy } \\
\text { management, and renewable energy use in public } \\
\text { buildings and in the housing sector }\end{array}$ & $663,678,472$ & \\
\hline & $\begin{array}{l}\text { 4.iii Support of energetic efficiency, smart energy } \\
\text { management, and renewable energy use in public } \\
\text { infrastructure }\end{array}$ & $34,642,124$ & \\
\hline & $\begin{array}{l}\text { 4.vi Promoting the use of high efficiency } \\
\text { cogeneration of heat and power based on useful } \\
\text { heat demand }\end{array}$ & $27,348,196$ & \\
\hline \multirow{3}{*}{4} & $\begin{array}{l}\text { 4.e and 4.v Promoting low emission strategies, } \\
\text { including support of sustainable multimodal urban } \\
\text { mobility and measures alleviating climate changes }\end{array}$ & $2,617,593,576$ & \multirow{3}{*}{$2,825,065,113$} \\
\hline & $\begin{array}{l}\text { 7.b Increase in regional mobility through } \\
\text { connecting nodes with TEN-T infrastructure, } \\
\text { including multimodal nodes }\end{array}$ & $161,590,184$ & \\
\hline & $\begin{array}{l}\text { 7.d Development and rehabilitation of complex, } \\
\text { high quality, and interoperational systems of } \\
\text { railway transport, and reducing noise }\end{array}$ & $45,882,353$ & \\
\hline \multirow[t]{2}{*}{5} & $\begin{array}{l}\text { 5.b Support of management systems and } \\
\text { investments aimed at specific types of threats, and } \\
\text { increasing resistance to catastrophes and natural } \\
\text { disasters }\end{array}$ & $133,200,201$ & \multirow[t]{2}{*}{$232,642,865$} \\
\hline & $\begin{array}{l}\text { 6.c Preservation, protection, promotion, and } \\
\text { development of natural and cultural heritage }\end{array}$ & $65,316,213$ & \\
\hline
\end{tabular}




\begin{tabular}{|c|c|c|c|}
\hline \multirow{2}{*}{ Indicator } & \multirow{2}{*}{ Investment priority } & \multicolumn{2}{|c|}{ Value in euro } \\
\hline & & Per priority & Total \\
\hline & $\begin{array}{l}\text { 6.d Protection and restoration of biological } \\
\text { diversity, protection and reclamation of soils, } \\
\text { support of ecosystem services }\end{array}$ & $34,126,450$ & \\
\hline \multirow{2}{*}{6} & $\begin{array}{l}\text { 6.a Investing in the waste management sector for } \\
\text { the purpose of meeting EU requirements }\end{array}$ & $43,878,184$ & \multirow{2}{*}{$212,004,346$} \\
\hline & $\begin{array}{l}\text { 6.b Investing in the water management sector for } \\
\text { the purpose of meeting EU requirements }\end{array}$ & $168,126,163$ & \\
\hline \multirow{6}{*}{7} & $\begin{array}{l}\text { 8.i Access to employment for persons searching for } \\
\text { jobs and professionally passive, including the long- } \\
\text { term unemployed }\end{array}$ & $66,921,858$ & \multirow{6}{*}{$299,442,802$} \\
\hline & $\begin{array}{l}\text { 8.iii Self-employment, entrepreneurship, and } \\
\text { creating enterprises and new workplaces }\end{array}$ & $48,996,557$ & \\
\hline & $\begin{array}{l}\text { 8.iv Gender equality and reconciling professional } \\
\text { and private life }\end{array}$ & $40,388,079$ & \\
\hline & $\begin{array}{l}\text { 8.v Adjusting employees, enterprises, and } \\
\text { entrepreneurs to changes }\end{array}$ & $6,255,420$ & \\
\hline & $\begin{array}{l}\text { 10.iii Alignment of access to lifelong learning, } \\
\text { improvement of workforce skills and competences }\end{array}$ & $9,217,863$ & \\
\hline & $\begin{array}{l}\text { 10.vi Adjustment of education and training systems } \\
\text { to the needs of the labour market }\end{array}$ & $127,665,023$ & \\
\hline \multirow{3}{*}{8} & 8.vi Active and healthy aging & $12,693,802$ & \multirow{3}{*}{$310,391,294$} \\
\hline & $\begin{array}{l}\text { 9.i Active inclusion, including promotion of equal } \\
\text { employment opportunities }\end{array}$ & $155,659,974$ & \\
\hline & $\begin{array}{l}\text { 10.i Counteracting early school leaving, provision } \\
\text { of equal accessibility to good quality education at } \\
\text { all levels of learning }\end{array}$ & $142,037,518$ & \\
\hline 9 & $\begin{array}{l}\text { 9.b Support of physical, economic, and social } \\
\text { revitalisation of the community, and urban and } \\
\text { rural areas }\end{array}$ & $456,495,067$ & $456,495,067$ \\
\hline \multirow{3}{*}{10} & $\begin{array}{l}\text { 9. Investments in health and social infrastructure, } \\
\text { transition from institutional services to the level of } \\
\text { local communities }\end{array}$ & $117,830,925$ & \multirow{3}{*}{$429,420,312$} \\
\hline & $\begin{array}{l}\text { 9.iv Facilitating access to affordable, sustainable, } \\
\text { high quality services, including health care and } \\
\text { social services }\end{array}$ & $109,580,271$ & \\
\hline & $\begin{array}{l}\text { 10.a Development of educational and training } \\
\text { infrastructure }\end{array}$ & $202,009,116$ & \\
\hline
\end{tabular}

Source: own work based on ITI Strategies. 
The data presented in Tab. 1 indicates that the largest financing applied to tasks whose implementation contributed to the development of balanced transport and improvement of mobility at the local and regional levels (SDI 4). The financial value of the planned tasks reached almost $47 \%$ of the total number of tasks for implementation under ITIs (Fig. 2). Among such tasks, the most resources will be allocated for the development of multimodal mobility in urban space and the implementation of innovative solutions thanks to which transport should influence climate changes less adversely. Moreover, an improvement of cities' transport accessibility at the regional level with the application of railway transport is assumed. Another sphere of support of sustainable development of cities in terms of the financing value is low emission economy and increase in the application of renewable energy sources (RES) (SDI 3). In total, tasks implemented within investment priorities concerning that indicator correspond to more than $14 \%$ of the total financial resources. The key task is the improvement of energy efficiency in the public sector, as well as in the housing sector.

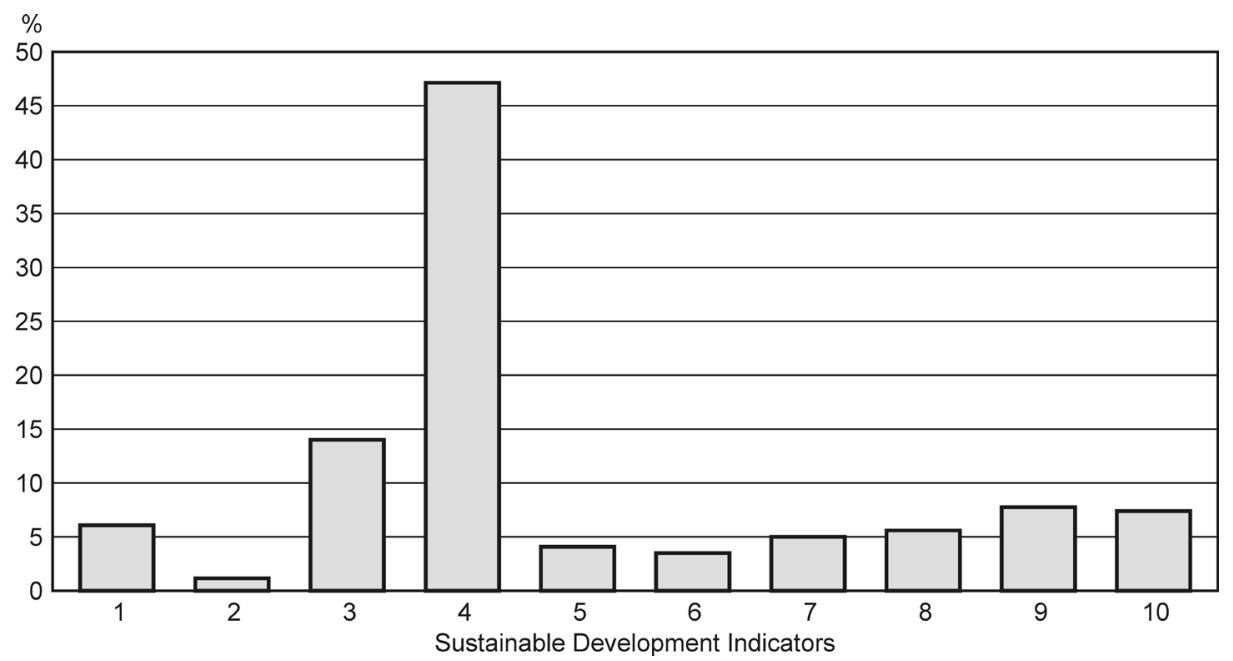

Fig. 2. Per cent share of the value of investments in the scope of ITIs in particular SDIs Source: own work.

The aforementioned two areas of sustainable development, i.e. sustainable transport and low emission economy, cover $61.1 \%$ of the financial value of projects implemented by ITIs. Those are investment projects of an infrastructural character, supported financially from resources of the European Regional Development Fund. The tasks, however, are not sufficient to obtain sustainable development of FUAs, and other supplementary tasks are required. Those include the remaining measures and projects corresponding to the remaining eight SDIs. In 
terms of the scale of financing, measures in the scope of regeneration are distinguished - SDI 9, the financing of which will consume $7.6 \%$ of ITI resources, and improvement of accessibility of public services (SDI $10-7.1 \%$ of resources). Both categories of measures have multi-aspect characters, and entail the strengthening of each dimension of sustainable development. Financing of measures for the development of modern, innovative, knowledge-intensive economy (in the scope of SDI $1-5.9 \%$ of resources) and the development of social activeness and integration (SDI $8-5.1 \%$ ) is also highly important. Financing the remaining measures under ITIs is conducted at a smaller scale, and the lowest share concerns creating conditions for integrated governance (SDI $2-0.8 \%$ ), where measures involve the development and implementation of an electronic system of governance for different areas of services and public administration.

Apart from the financial aspect, the common character of the implemented measures and their spatial variability is also important. 309 projects were designated for implementation through ITIs in the scope of the discussed IPs. Their scale of variability in substantive and spatial terms are lower in the case of financing, but groups of the most commonly undertaken measures can be distinguished (Fig. 3). Those include 53 projects (17.5\% of the total number) for the development of the labour market (SDI 7). Measures undertaken in their scope do not only involve the adjustment of the unemployed to accepting employment, but most of all the adjustment of the education and training systems to the needs of the market (18 measures in IP 10.iv), as well as self-employment and promotion of entrepreneurship (11 in IP 8.iii). Those are of a prospective character, contributing to the creating conditions for undertaking employment, and not an elimination of unemployment which in FUAs is on a relatively low level when compared to the rest of the country. The improvement of the quality and accessibility of public services (SDI 10) is yet another area strongly represented in the scope of the undertaken measures. Its greatest part is related to investments in the development of education and training infrastructure (19 projects in the scope of implementation of IP 10.a), as well as healthcare (15 in IP 9.a). Commonly implemented measures also include those aimed at developing a balanced transport system and improving mobility at the local and regional scale (SDI 4). In that case, the number of projects is adequate to the variability of the scale of their financing, and their highest number applies to the development of sustainable multimodal mobility population in urban areas (32 projects under IP 4.e and 4.v). The group of measures distinguished in terms of the number of projects also includes those which are related to supporting social activeness and integration (SDI 8), particularly counteracting school dropouts, and providing equal access to good equality education at every level (20 projects in IP 10.i). Fewer projects, 16 in total, involve the implementation of tasks in the scope of the rationalisation of municipal economy (particularly waste and water management) (SDI 6) and regeneration (SDI 9), and the least - those concerning integrated governance (SDI 2 - only 8 projects). 


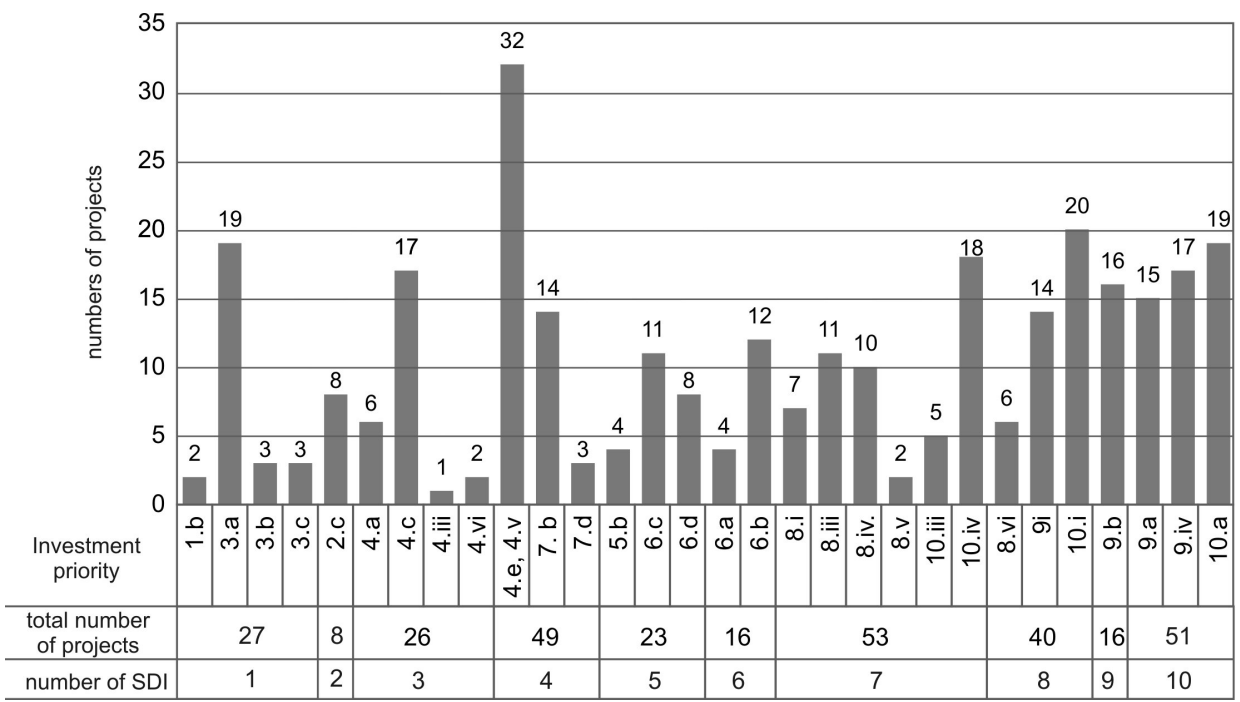

Fig. 3. Number of ITI projects implemented in the scope of a particular SDI with the corresponding IP Source: own work.

In the context of supporting sustainable development, it is beneficial to undertake measures influencing the economic, social, and environmental spheres of development in each FUA. Considering the complex nature of the undertaken measures in the analysed areas, in the majority of cases the tasks in the scope of several SDI are implemented (Fig. 4). Units showing the greatest diversity of undertaken measures are functional areas of cities in Lower Silesia and Silesia, i.e. FUAs of: Wrocław (22 tasks), Wałbrzych (20 tasks), Jelenia Góra (16 tasks), Katowice (21 tasks), Częstochowa (19 tasks), Rybnik (17 tasks), and Bielsko-Biała (13 tasks). A group with implementation of approximately 10 various tasks in the scope of sustainable development includes some of the largest urban centres in the country, i.e. Poznań, Cracow, Łódź, Tricity, as well as Lublin, Bydgoszcz, and Torun. The lowest diversity applies to centres in north-east Poland (Ełk FUA, Elbląg FUA, Białystok FUA, Olsztyn FUA), but also Warsaw FUA, and Szczecin FUA. The most popular ITI tasks promoting sustainable development of cities and their functional areas include those implemented in the scope of SDI 4, and particularly in IP 4.e and 4.v., implemented in 24 out of 26 of the analysed FUAs. Those are followed by tasks in the scope of stimulating social activeness and integration (SDI 8) and the development of the labour market (SDI 7), each implemented in 23 of the analysed FUAs. The least popular are the measures in the scope of SDI 2 regarding building integrated governance systems, undertaken in 8 FUAs, as well as those concerning rational municipal management (SDI 6), implemented in 12 FUA. 


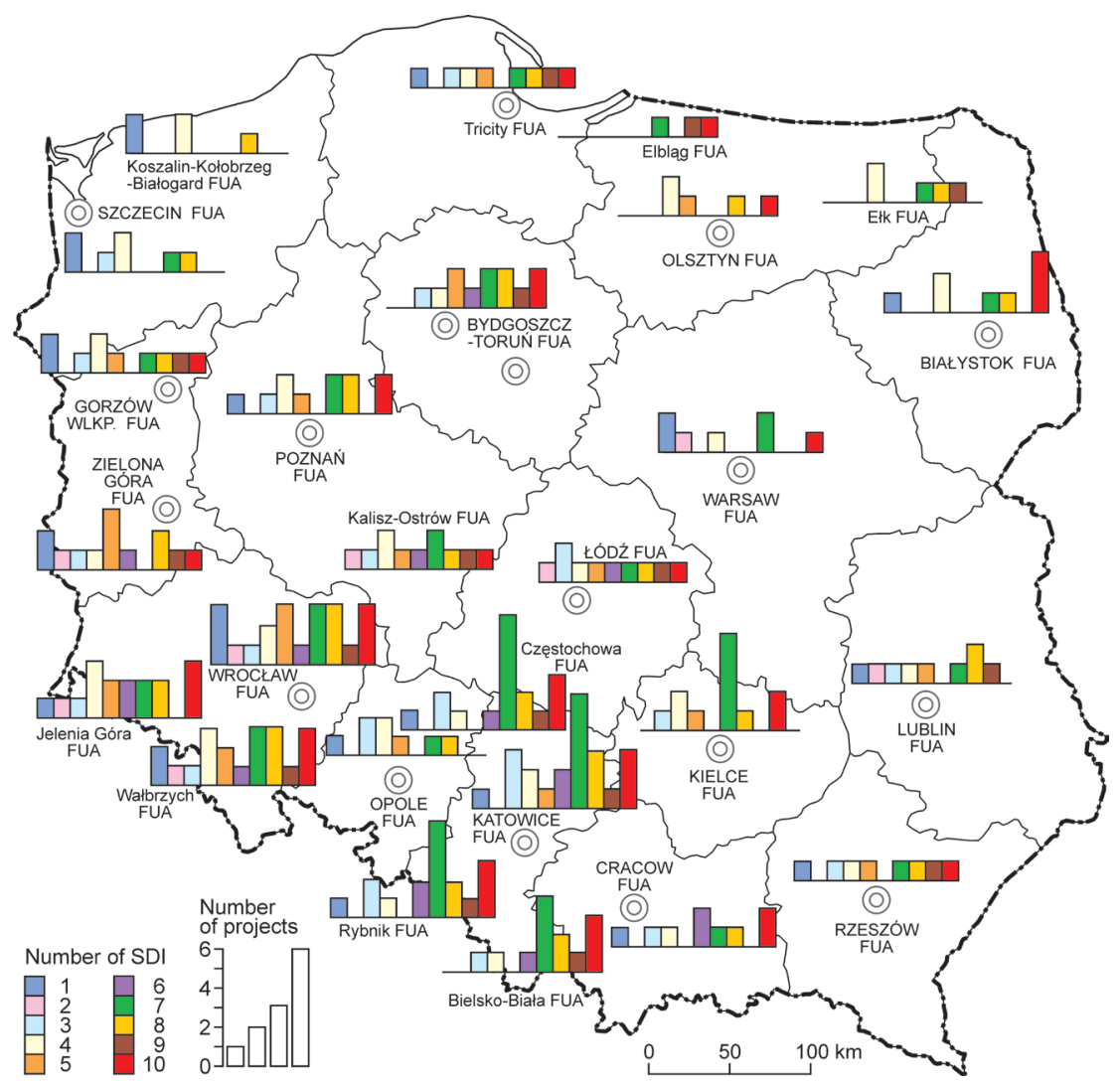

Fig. 4. Implementation of SDIs in the analysed FUA

Source: own work.

\section{CONCLUSIONS}

Functional urban areas, whose development should be aimed at the efficient utilisation and the stimulation of their socio-economic and spatial potentials with simultaneous provision of high quality of life of residents, are the direct subjects of the implementation of the rules of sustainable development in the current perspective. To obtain sustainable development it is necessary to improve the operating conditions in all its spheres: economic, social, and environmental, but it should be determined by local circumstances. Such possibilities in the programming-financial and legal spheres are offered by Integrated Territorial Investments (ITIs). In the context of a lack of tools for the assessment of the 
effects of the implementation of ITIs on sustainable development of cities and their functional areas, this paper proposes a group of Sustainable Development Indicators (SDIs) filling the research gap, and presents results of their application at the initial stage of the implementation of the ITI instrument in functional urban areas in Poland.

The study shows that the scope of measures adopted for implementation in the form of ITIs can influence the implementation of the concept of sustainable development in FUAs, although to different degrees. The adopted SDIs cover all measures implemented by FUAs through ITIs. The contribution of a particular IP, and therefore measures undertaken in their scope in the SDI structure, however, is different. From the point of view of the number of adopted IPs, the greatest support through ITIs applies to the development of a structurally diverse labour market, and at the smallest extent - integrated management and regeneration. The remaining SDIs are implemented in the scope of a comparable, proportionate number of IPs. In order to complete the analysis, it is justified to identify the number of measures and the scale of their financing with simultaneous reference of the results to local conditions. The complete analysis showed more variable results. Therefore, the proposal for the new tool for assessing/evaluating the scope of impact of ITIs on sustainable development of FUAs can be considered as contributive to the cognition of the process in reality.

The analysis conducted for the 26 FUAs in Poland by means of SDIs showed that in general, measures undertaken under ITIs can contribute to shaping good conditions for their sustainable development. The impact of such measures for sustainable development, however, is variable both in terms of the implementation of SDIs, and their complexity, and it reveals territorial variability. The study indicated that the dominant sphere in which the highest number of projects is implemented and which consumes the highest amount of financial resources is the modernisation of the transport and energy infrastructure the effects of which should have multiple aspects. That particularly applies to tasks in the scope of SDI 3 and SDI 4, directly corresponding to the priorities of the development of the European Union in the 2014-2020 period (cf. Szafranek, 2017), and implemented in the majority of the analysed FUAs. Their implementation will contribute to the sustainable development of cities, particularly in the economic and environmental, and indirectly also social aspect. The latter aspect is reinforced by means of a large-scale implementation of measures and investments adjusting resources to changing conditions in the labour market, commonly and permanently implemented in the analysed FUAs (cf. Szafranek, 2017). It is disturbing that the least attention in strategic programming of the development of FUAs, both in terms of financing and implementation, is paid to the strengthening of integrated governance, providing the basis for the success of the implementation of ITIs. Units showing the highest diversity of undertaken measures are functional areas of cities in Lower Silesia and Silesia, and the lowest - subregional centres which not only 
obtained the lowest financial support for the implementation of ITIs, but also have no experience in earlier cooperation of LGU. It should also be emphasised that the high diversity and spatial variability of tasks in the scope of sustainable development implemented in the form of ITIs depends on the development policy of particular regions and the availability of financial capital, and their effectiveness and efficiency will depend on the involvement of ITI Unions and local government units included in FUAs, which in the context of low interest in the implementation of SDI 2 does not bode well for the future.

The application of SDIs in combination with IPs permitted the identification of the scale and structure of the undertaken measures for sustainable development of FUAs in Poland. Similar results can presumably be obtained through analyses of analogical territorial units throughout the European Union. The continuation of the study can help determine the extent to which the implementation of ITIs actually supports sustainable development of cities and their functional areas. The results of future research can be used in formulating recommendations for the implementation of the tool in the coming financial perspective.

\section{REFERENCES}

ADAMS, W. M. (1990), Green development: Environment and sustainability in the third world, London: Routledge.

ADAMS, W. M. (2006), The future of sustainability: Re-thinking environment and development in the twenty first century, Report of the IUCN-Renowned Thinkers Meeting.

BARCA, F. (2009), An Agenda for a Reformed Cohesion Policy, A place-based approach to meeting European Union challenges and expectations, Independent Report for DG Regio, Brussels: European Commission.

BARCA, F., McCANN, P. and RODRÍGUEZ-POSE, A. (2012), 'The Case For Regional Development Intervention: Place-Based Versus Place-Neutral Approaches'. Journal of Regional Science, 52 (1), pp. 134-152.

BARTNICZAK, B. (2016), 'Sustainable development concept in Polish strategic documents', Economic and Environmental Studies, 16 (1) (37/2016), pp. 49-63.

BORYS, T. (1998), ‘Teoretyczne aspekty konstruowania wskaźników ekorozwoju', [in:] POSKROBKO, B. (ed.), Sterowanie ekorozwojem, Białystok: Wydawnictwo Politechniki Białostockiej.

BORYS, T. (2005), 'Wąskie i szerokie interpretacje zrównoważonego rozwoju', [in:] PAPUZIŃSKI, A. (ed.) Zrównoważony rozwój. Od utopii do praw człowieka, Bydgoszcz: Oficyna Wydawnicza Branta.

BORYS, T. and CZAJA, S. (2009), 'Badania nad zrównoważonym rozwojem w polskich ośrodkach naukowych', [in:] KIEŁCZEWSKI, D. (ed.) Od koncepcji ekorozwoju do ekonomii zrównoważonego rozwoju, Białystok: Wyższa Szkoła Ekonomiczna w Białymstoku.

BROWN, L. (2001), Eco-economy: Building an economy for the earth, New York: W. W. Norton.

BYRNE, J. and GLOWER, L. (2002), 'A Common Future or Towards a Future Commons: Globalization and Sustainable Development since UNCED', International Review for Environmental Strategies, 3 (1), pp. 5-25.

DANIELEWICZ, J. (2017), 'The Sustainable Development Idea in the Management of European Metropolitan Areas', Economic and Environmental Studies, 17 (2), pp. 279-296. 
DEMBICKA-NIEMIEC, A. (2017), Zrównoważony rozwój a funkcje miast. Badanie zwiąków miedzy zrównoważonym rozwojem średnich miast w Polsce a ewolucją ich struktury funkcjonalnej, Opole: Wydawnictwo Uniwersytetu Opolskiego, pp. 51-67.

DIWAN, R. K. and LIVINGSTON, D. (1979), Alternative Development Strategies and Appropriate Technology, New York: Pergamon Press.

DOBSON, A. (1996), 'Environmental sustainabilities: An analysis and a typology', Environmental Politics, 5, pp. 401-428.

Europe 2020, A European strategy for smart, sustainable and inclusive growth, Brussels, 3.3.2010 COM(2010) 2020 final, http://ec.europa.eu/eu2020/pdf/COMPLET\%20 EN\%20BARROSO\%20\%20\%20007\%20-\%20Europe\%202020\%20-\%20EN\%20 version.pdf (9.11.2017)

European Commission (2014), Integrated Territorial Investment, Cohesion Policy 2014-2020, Luxembourg: Office for Official Publications of the European Communities. http://ec.europa.eu/ regional_policy/sources/docgener/informat/2014/iti_en.pdf (5.11.2017).

FAROLE, T., RODRÍGUEZ-POSE, A. and STORPER, M. (2011), 'Cohesion policy in the European Union: growth, geography, institutions', JCMS: Journal of Common Market Studies, 49 (5), pp. 1089-1111.

FIEDOR, B. (2011), 'Zrównoważony rozwój a koncepcja społecznej gospodarki rynkowej', Prace Naukowe Uniwersytetu Ekonomicznego we Wrocławiu/Research Paper of Wrocław University of Economics, 225, pp. 13-29.

GALAZ, V. (2014), Global Environmental Governance, Technology and Politics. The Anthropcene Gap, Cheltenham: E. Elgar Publ.

GIOVANNINI, E. and LINSTER M. (2005), Measuring sustainable development. Achievements and challenges, OECD.

HARDIN, G. (1968), 'The tragedy of the commons', Science, 162 (3859), pp. 1243-1248.

HAWKEN, P., LOVINS, A. and LOVINS L. H. (1999), Natural capitalism: Creating the next industrial revolution, Boston: Little, Brown and Company.

HENS, L. (2010), 'The challenge of the sustainable city', Environment, Development and Sustainability, 12 (6), pp. 875-876.

HULL, Z. (2011), 'Wprowadzenie do filozofii zrównoważonego rozwoju' [in:] TYBURSKI, W. (ed.) Zasady ksztaltowania postaw sprzyjających wdrażaniu zrównoważonego rozwoju, Toruń: Wydawnictwo UMK, p. 33-83.

KACZMAREK, T. and KOCIUBA, D. (2017), 'Models of governance in the urban functional areas: Policy lessons from the implementation of integrated territorial investments (ITIs) in Poland', Quaestiones Geographicae, 36 (4), pp. 47-64.

KASSENBERG, A. (2007), 'Zrównoważony rozwój a koncepcja przestrzennego zagospodarowania kraju', [in:] GORZELAK G. and TUCHOLSKA, A. (eds.) Rozwój, region, przestrzeń, Warszawa: Ministerstwo Rozwoju Regionalnego, EUROREG.

KOCIUBA, D. (2017), 'Zintegrowane Inwestycje Terytorialne jako narzędzie zarządzania terytorialnego w miejskich obszarach funkcjonalnych', Studia KPZK PAN, 174, pp. 144-153.

LAFFERTY, W. (1999), 'The pursuit of sustainable development - concepts, policies, and arenas', International Political Science Review, 20 (2), pp. 123-128.

Leipzig Charter On Sustainable European Cities (2007), http://ec.europa.eu/regional_policy/archive/themes/urban/leipzig_charter.pdf (12.11.2017)

LEŚNIAK, J. (2009), 'Wizja zrównoważonego społeczeństwa', [in:] BŁAŻEJOWSKI, J. (ed.) Zrównoważony rozwój, Gdańsk: Gdańskie Towarzystwo Naukowe.

MARCIAL, H., ECHENIQUE, M. H., HARGREAVES, A. J., MITCHELL, G. and NAMDEO A. (2012), 'Growing Cities Sustainably', Journal of the American Planning Association, 78 (2), pp. 121-137. 
McCANN P. and ORTEGA-ARGILÉS R. (2013), 'Redesigning and Reforming European Regional Policy: The Reasons, the Logic, and the Outcomes', International Regional Science Review, 36, pp. 424-445.

MIERZEJEWSKA, L. (2015), 'Miasto zwarte, rozproszone, zrównoważone', Studia Miejskie, 19, pp. 9-22.

MIERZEJEWSKA, L. (2017), 'Sustainable Development of a City: Systemic Approach', Problemy Ekorozwoju/ Problems of Sustainable Development, 12 (1), pp. 71-78.

National Spatial Development Concept 2030 [Koncepcja Przestrzennego Zagospodarowania Kraju 2030] (2011), Warszawa: Ministerstwo Rozwoju Regionalnego, mr.bip.gov.pl/fobjects/download/48478/kpzk_uchwala_zal_do240_13042012-pdf.html (10.11.2017).

National Urban Policy 2023 [Krajowa Polityka Miejska 2023] (2015), Warszawa: Ministerstwo Infrastruktury i Rozwoju. http://obserwatorium.miasta.pl/wp-content/uploads/2015/08/Krajowa_Polityka_Miejska.pdf (18.11.2017).

PAPUZ̄IŃSKI, A. (2011), 'Realizacja zrównoważonego rozwoju', Problemy ekorozwoju/ Problems of Sustainable Development, 6 (1), pp. 107-116.

PEARCE, D. W. and TURNER, R. K. (1990), Economics of natural resources and the environment, London: Harvester Wheatsheaf, pp. 25-41.

PIĄTEK, Z. (2007), 'Przyrodnicze i społeczno-historyczne warunki równoważenia ładu ludzkiego świata', Problemy ekorozwoju/ Problems of Sustainable Development, 2(2), pp. 5-18.

PŁACHCIAK, A. (2011), 'Geneza idei rozwoju zrównoważonego', Ekonomia/ Economics, 5 (17), pp. 231-247.

Principles of The Realization of The Integrated Territorial Investments in Poland [Zasady realizacji Zintegrowanych Inwestycji Terytorialnych w Polsce] (2013), Warszawa: Ministerstwo Infrastruktury i Rozwoju, https://rpo.slaskie.pl/dokument/zasady_realizacji_it_w_polsce (12.11.2017).

Programming of the 2014-2020 Financial Perspective. Partnership Agreement [Programowanie perspektywy finansowej 2014-2020. Umowa Partnerstwa] (2014), Warszawa: Ministerstwo Infrastruktury i Rozwoju, https://ec.europa.eu/info/sites/info/files/partnership-agreement-poland-may2014_pl.pdf (3.11.2017).

REID, D. (1995), Sustainable development: An introductory guide, London: Earthscan.

SADOWSKI, Z. (2006), 'Współczesna gospodarka, rola państwa i koncepcja trwałego rozwoju', Czasopismo Naukowe OLYMPUS, 1, pp. 11-20.

SNEDDON, C., HOWARTH R. B. and NORGAARD, R.B. (2006), 'Sustainable development in a post-Brundtland world', Ecological Economics, 57, pp. 253-268.

STANNY, M. and CZARNECKI, A. (2011), Zrównoważony rozwój obszarów wiejskich Zielonych Ptuc Polski. Próba analizy empirycznej, Warszawa: Instytut Rozwoju Wsi i Rolnictwa PAN.

SZAFRANEK, E. (2014), 'Integrated Territorial Investments as a tool of sustainable regional and local development', Economic and Environmental Studies, 14,4 (32), pp. 485-495.

SZAFRANEK, E. (2017), 'Idea a praktyka wdrażania Zintegrowanych Inwestycji Terytorialnych w Polsce', Studia KPZK PAN, 174, pp. 95-106.

SZLACHTA, J. and ZAUCHA, J. (2012), For an enhanced territorial dimension of the cohesion policy in Poland in the 2014-2020 period, Sopot: Instytut Rozwoju.

SZLACHTA, J. and ZAUCHA, J. (2014), 'Wzmacnianie terytorialnego wymiaru polityki spójności w Polsce w latach 2014-2020', [in:] KLASIK, A. and KUŹNIK F. (eds.) Miasta - metropolie - regiony. Nowe orientacje rozwojowe, Katowice: Wydawnictwo Uniwersytetu Ekonomicznego w Katowicach, pp. 29-54.

ŻYLICZ, T. (2000), 'Sprawiedliwość międzypokoleniowa jako podstawa trwałego rozwoju', [in:] ZIĘBA, S. and WRÓBLEWSKI, Z. (eds.), Ekologia a transformacje cywilizacyjne na przełomie wieków, Lublin: Katolicki Uniwersytet Lubelski, pp. 227234. 